\title{
UKRAINIAN AIRCRAFT CONSTRUCTION AS THE PRECONDITION OF EMERGENCE OF DOMESTIC AVIATION EDUCATION
}

\section{Yana Necheporuk ${ }^{1}$}

${ }^{1}$ Ph.D. (Pedagogy), postdoctoral student of Pedagogy and education management department, Volodymyr Vynnychenko Central Ukrainian State Pedagogical University, Kropyvnytskyi, Ukraine, e-mail: yananecheporuk83@gmail.com,ORCID: https://orcid.org/0000-0003-1152-8030

Abstract. The historical preconditions for the emergence of the domestic system of civil aviation flight training in Ukraine were its active actions in the process of the development of aviation and aircraft construction. The particular aim of this article is to study the historic development of Kyiv Polytechnic Institute, to find out how it became the cradle of Ukrainian aviation and plane construction, to highlight and characterize the key persons who influenced the development of the domestic aircraft industry, to give the comparative characteristics to old educational and modern principles of aircraft constructors training. To solve the tasks of the article, a set of research methods was used, due to its subject, goals and objectives: comparative analysis (theoretical analysis, synthesis, generalization, systematization of scientific sources, periodicals to solve this problem and clarify the conceptual apparatus of the study); chronological and diachronic (determination the development and essential changes in preparing the aircraft construction personnel in KPI); search and bibliographic (systematization and classification of pedagogical, methodical, scientific literature, archival materials, periodicals on the aeronautical achievements in Kyiv Polytechnic Institute); comparative and historical (analysis and comparison of socio-pedagogical phenomena that make it possible to identify positive inputs in Ukrainian aviation industry).

Comparing educational methods at the beginning of the XX century and the beginning of the XXI century, it should be noted that now in addition to generating talented ideas the student should have many professional competencies. In addition to strict requirements for future specialists, the state also makes certain requirements for higher education institutions that train future aircraft designers.

Keywords: Aviation, construction, aeronautical education, Kyiv Polytechnic Institute

JEL Classification: JEL I0; I20

Formulas: 0; fig.: 0; tabl.: 0; bibl.: 11

Introduction. The main purpose of those who were directly involved in the formation and development of aviation was to fly on an aircraft heavier than air. At that time, such activities were considered as fun for individual enthusiasts. However, later aviation turned from a curiosity into an extremely important technical and social phenomenon. Kyiv Polytechnic Institute was a place where great scientists were solving the problems and spreading the ideas of aviation in Ukraine.

Literature Review. A big number of works written by domestic and foreign scientists were dedicated to a matter of theoretical and practical research aspects of aviation industry development: I. Gayets, Yu. Slyusarenko, A. Kalinovskyi, N. Horbal, N. Kalinovskaya, O. Labunets, A. Hrushevytska, O. Svezhentsev.

Many scholars and researchers have been studying various aspects of the history of Kyiv Polytechnic Institute. They consistently covered the structure, the main stages of KPI's activity, paid special attention to the most important achievements in the training of highly qualified engineers, the activities of leading scientific schools and areas. Among them were G. Belyakov, Y. Vasylenko, M. Vilkov, S. Gavrish, F. Gorovskyi, M. Zavinovskyi, M. Karpenko, M. Ilchenko, V. Kirichuk, B. Novikov, 
N. Palamarchuk, V. Pikhov, G. Rakitina, L. Savchuk, R. Slipenky, T. Stepanenko, B. Tsyganok, V. Chobitok, V. Shekhovtsov.

Kyiv Polytechnic Institute was opened in 1898. At that time the institute had four departments: mechanical, chemical, civil engineering and agricultural. on Over time, on the basis of KPI there were established 12 universities in many regions of Ukraine, 9 of them have the status of national: Kyiv National University of Construction and Architecture, Kyiv National University of Technology and Design, National Aviation University, National University of Food Technologies, Odessa National Maritime Academy, Vinnytsia National Technological University and so on [8, p.217-220].

It should also be noted, that the interest in aeronautics was not something new for the institute. The first suggestions to create the additional fifth aeronautical department were made straight in 1899 year. Firstly, it was not about the preparation of plane construction specialists. For that period, such machines were just a dream for domestic engineers and scientists, but about the specialists who will work in the sphere of aeronautics. The head of the new department was one of the greatest aviation enthusiast professor Nikolai Artemiev, a talented student of Nikolai Zhukovsky.

Professor Stepan Tymoshenko became the first honorary chairman of this section, and Viktoryn Flavianovych Bobrov, a student of the mechanical department, became its vice-chairman.

It was a century ago when the first graduation of specialists completed the full course of KPI. The new high technical educational institution immediately declared itself to be of high quality for its graduates. Dmitryi Mendeleev, who graduated from KPI engineers in 1903, noted that in 35 years of his pedagogical activity he had not met in other educational institutions such a complete set of theoretical knowledge and practical skills as the first graduates of Kiev Polytechnic. They really made a significant contribution in the development of various fields of technology. Aviation that had been developing rapidly in the early twentieth century was not an exception [7, p.32-33].

During 1907-1908, Professor Artemyev conducted experiments with the «flywheel-propeller» model, which was a steel flywheel on a vertical axis with rotating blades mounted on it. In the winter of 1908-1909, Professor Artemyev and the famous aviator Boris Delone tested large models of gliders (with a wingspan of up to 3 meters), launching them with a catapult with a powerful spring from the car buffer. Later, Mykola Artemyev together with KPI professor Oleksandr Kudashev took part in the construction of the first glider and plane in Kyiv.

A passionate aviation engineer and active developer the ideas of aviation and gliding was KPI Professor Mykola Delone, the son of aviation pioneer Borys Delone. In early 1896, he began systematic experiments with glider models in New Alexandria near Warsaw, where he headed the department at the Institute of Agriculture. Since 1906, when the Aeronautical Section was established at the KPI, Mykola Delone became the permanent leader of the aeronautical section that later was transformed into Kyiv Aeronautical Society. This first aviation center in the 
south of Russia brought together not only well-known professors, engineers and designers at the time, but also KPI students who were in the forefront of those who paved the way to heaven $[9, \mathrm{p} .314]$.

Members of the aeronautical section listened to lectures, which were held by professors of KPI and the St. Volodymyr University. They also wrote their own scientific essays and reports on aviation, built and tested flying models, kites, gliders. Student Ergand built quite successful flying models. Students Adler and Savitsky conducted experiments with a glider attached to a bicycle. Later, members of this section built one of the first tugboats in Russia.

At the end of 1908, Professor Mykola Zhukovsky arrived in Kyiv. In the premises of the Merchants' Meeting (now the Kyiv Philharmonic) he gave a public lecture «Successes of Aeronautics», during which there were shown short aeronautical newsreels. At the request of majority of students and teachers, Mykola Delone repeated this lecture in a large KPI physical auditorium. Later, Professor Delone repeatedly lectured on aeronautics and gliding in Kiev, Kharkov, Poltava, Uman, Ekaterinoslav, Yelisavetgrad, Moscow, Orel and Vilnius.

In spring of 1909, Professor Delone, with his sons and KPI teachers Hanitsky and Garf, built his first glider, a biplane with balance control. Professor Delone later built three more gliders. In 1909, the KPI Aeronautical group, led by Professor Delone, brought together about 200 enthusiasts who studied the theoretical foundations and techniques of aviation, tried to build gliders and aircraft. Among them are KPI students, future aviators Sikorsky, Bilinkin, Karpeka, Adler and others. He himself developed and gave a course of lectures on aeronautics.

However, the members of the section not only listened to lectures and studied the theoretical foundations of aviation but also performed practical activities - they designed and constructed their own devices. No wonder that the largest number of domestic aircraft designers came from the walls of the Polytechnic Institute. Among them Igor Sikorskyi, Dmitry Grigorovich, Fedor Tereshchenko, Fedor Bylinkin, Georgy Adler, Alexander Karpeka, brothers Kasyanenko and others. During the period from 1909 to 1912, Kyiv enthusiasts created about 40 different types of aircraft more than in any other city in Russia.

One of the brightest figures of the Kiev aircraft construction school was an outstanding designer with a worldwide reputation Igor Sikorsky (1889-1972). In autumn 1907, he entered the KPI, where he studied until 1911. Sikorsky became one of the active participants in the helicopter section, which was headed by one of the Kasyanenko brothers - Andrii Ivanovych. In the summer of 1908 Igor Sikorskyi began to develop his first helicopter, and in 1909 its practical construction. Unfortunately, the first helicopter could not take off.

Taking into account testing results, in the spring of 1910 Igor Sikorsky created his second helicopter, but it also was not able to take off.

At the same time, simultaneously with the helicopter testing, Igor Sikorskyi began to develop his first airplane. He was working with the son of a Kiev merchant Fedor Bilinkin, who already had some experience in this matter. The biplane was named BIS №1 (Bilinkin, Jordan, Sikorskyi). Then it was reconstructed into a BIS 
№2 aircraft. On the $3^{\text {rd }}$ of June in 1910 in the presence of sports commissioners of the Kiev Aeronautic Society Igor Sikorsky performed a successful flight. It was a straight flight with a length of 182 meters at an altitude of 1.2 meters and it lasted 12 seconds. Subsequently, it was accomplished about 50 flights at an altitude of 10 meters, but with a short duration.

On his next C-3 plane, Igor Sikorskyi passed exam and got the title of pilotaviator. During that flight he made five «Eights» in the air and landed safely. Russian Imperial Airclub on behalf of the International Aviation federation issued him a pilot's license for № 64. On general meeting of the Imperial Russian Technical Society on January 21, 1912 Igor Sikorsky was awarded the medal «For Useful Works in sphere of aeronautics and for independent development of the airplane of own system that gave fine results».

After leaving to the United States, Igor Sikorskyi developed more than 65 designed aircraft. From 1939 until the end of his days, he designed and built helicopters one of the best in the world.

Brothers Yevgenyi, Ivan, Andrii and Grigoryi Kasyanenko are rightly considered the founders of Ukrainian aviation. As soon as it was founded the Aeronautical Section at the KPI, Yevgenyi Kasyanenko headed the section «Airplanes», and Andrii - «Helicopters». In addition to scientific and organizational work, they carried out effective design activities. Since 1910 till 1921, the brothers created six planes.

The beginning of the First World War greatly affected the work of the Institute. The aeronautical section stopped its activity - most of its members were mobilized in the aviation military units. But already in 1915 it started again its activity in the sphere of aviation.

Since 1920, under the leadership of an energetic rector Victorina Bobrova at KPI begins a serious restructuring - with significant changes in the educational process, re-equipment of the material base of the institute. Note that V. Bobrov's interest in the training of national personnel of aircraft manufacturers was not accidental - while ha was a student, for many years he was the permanent secretary of the Aeronautical section in Kyiv Polytechnic Institute. As soon as he graduated and during the First World War and the Civil War he served as a mechanical engineer in aircraft repair units, was involved in the organization of aviation production. Victorin Bobrov by the time of appointment to the post of rector headed the plant «Remvozduh-6» the first aviation factory on the territory of Ukraine (now it is the world famous Kyiv state aviation plant «Aviant»).

Since 1922, the work of the Aeronautical section was restored, in next year it turns into Aviation Scientific Technical society, and in 1924 it became a basis for separate aircraft construction faculty. Over time, KPI opened an aviation department that in 1933 was transformed into Kiev Aviation Institute, now known as National Aviation University.

Aims. The particular aim of this article is to study the historic development of Kyiv Polytechnic Institute, to find out how it became the cradle of Ukrainian aviation and plane construction, to highlight and characterize the key persons who influenced 
the development of the domestic aircraft industry, to give the comparative characteristics to old educational and modern principles of aircraft constructors training.

Methods. To solve the tasks of the article, a set of research methods was used, due to its subject, goals and objectives: comparative analysis (theoretical analysis, synthesis, generalization, systematization of scientific sources, periodicals to solve this problem and clarify the conceptual apparatus of the study); chronological and diachronic (determination the development and essential changes in preparing the aircraft construction personnel in KPI); search and bibliographic (systematization and classification of pedagogical, methodical, scientific literature, archival materials, periodicals on the aeronautical achievements in Kyiv Polytechnic Institute); comparative and historical (analysis and comparison of socio-pedagogical phenomena that make it possible to identify positive inputs in Ukrainian aviation industry).

Results. The aviation traditions of KPI are still alive. However, domestic aviation industry has become cramped in its cradle, and today our country has a powerful scientific and production potential. Today the aviation industry of Ukraine unites about 40 high-tech enterprises and organizations. The main is the state aircraft construction concern «Antonov», which includes the Aviation Science and Technology Complex, Kyiv Aviation Plant «Aviant», Kharkiv State Aircraft Manufacturing Enterprise and Kiev Civil Aviation Aircraft Repair Plant No. 410.

It has more than 20 types of original civil, military transport and special aircraft, and also about 100 modifications of aviation equipment. The world's largest aircraft An-225 is widely known («Mriya»). The field of activity of the Antonov’s giant An124 («Ruslan»). In recent years Antonov's concern developed a military transport aircraft with short takeoff and landing - An-70.

Due to the fact that the design bureau of Oleg Antonov began to operate in Kiev, the Ukrainian aircraft industry received a very big boost for development. Many factories in Ukraine began to produce products, which were used to build Antonov's aircraft. Oleg Antonov is a Soviet aircraft designer who made an inexhaustible contribution to the development of world aircraft construction, and Ukrainian aircraft in particular. In 1952, together with his design bureau, he moved to Kyiv, where he began to fulfill the task of the authorities, namely the construction of a military transport aircraft with two turboprop engines. The task was completed, and the first designed An-8 plane took off on February 11, 1956. The An-22 set 41 world aviation records.

Soon he began to develop and build the An-10 and An-12 and the passenger An14, An-24 and An-28. Later, the An-22 Antey was designed - the world's first widefuselage aircraft, which in size surpassed anything that had been done in aviation until then, breaking records for speed, load capacity and altitude [8, p.284-290].

Accordingly, his direct work as the general designer of this office, led to the growth of the aviation industry throughout our country and we still enjoy the results of his work in this area. Thanks to the work of these enterprises, our country is known all over the world in the aviation sector. 
Discussion. Unfortunately, nowadays Ukrainian aircraft construction is not the most developed in the world, as Ukraine does not have sufficient economic potential for financial promotion of such a scientific and capital-intensive industry, but certain types of aircraft construction (especially transport aircraft construction) in Ukraine still got a good result. Currently, evaluation is relevant the state of the aircraft industry in Ukraine and the search for new ones promising markets.

Taking into account the historic and current state of Ukrainian aircraft construction, it should be noted that the beginning of the twentieth century was a period of prosperity of domestic aircraft construction for Ukraine. At that time, the country was concerned not only with the material support of this industry, but also with the quality training of aviation personnel. For example, expansion of the Antonov State Enterprise possible due to the implementation of existing counter-acts, the opening of service centers in countries where aircraft are imported; it is necessary to search for new ones markets and partners [11].

In addition to Antonov's own desire to restore its power in the field of Ukrainian aircraft construction, we now have serious state support. The concern is starting to produce cargo planes without any Russian components. This is an unprecedented event at this stage. At all meetings of Antonov's representatives with potential counterparts, the Russians tried to convince that the Ukrainian plane would simply not take off into the sky, and that the Russian Federation was capable of blocking any such possibility. But Ukraine has proved to the world that it can do it. Verkhovna Rada completed the legislative reform of the aircraft industry of Ukraine, creating conditions for a temporary, until January 1, 2025, reduction of the tax burden on the aviation industry: exemption from value added tax, land tax and corporate income tax; increasing the list of goods imported by aircraft manufacturers without paying import duties, as well as the abolition of benefits for temporary importation under the terms of operating leases of individual aircraft.

During the process of lobbying these laws, deputies have set an ambitious goal to return our country to the status of a powerful aviation state. This once again shows that the parliament can consolidate, unite around fundamental decisions for the state, iconic areas. It is at such moments that national interests become higher than political ambitions.

Conclusion. Now in Ukraine there are qualitative standards of education in the specialty 134 Aviation and rocket-space technology. Comparing educational methods at the beginning of the XX century and the beginning of the XXI century, it should be noted that now in addition to generating talented ideas the student should have many professional competencies. The main of them are:

- fluent oral and written communication in Ukrainian and foreign languages on professional issues;

- understand environmentally hazardous and harmful professional factors activities and adjust its content in order to prevent negative impact on environment;

- specialists have to manage the means of modern information and communication technologies to an extent sufficient for training and professional activities; 
- aeronautical engineer must explain their decisions and ideas to specialists and nonspecialists in a clear and unambiguous form;

- have the skills of independent learning and self-studying to improve professional skills and solve problems in a new or unfamiliar environment;

- to form substantiated assessments of actions of state bodies, others political institutions from the standpoint of universal, democratic values, priority of human and civil rights and freedoms;

- have the logic and methodology of scientific knowledge that is based on an understanding of the current state and methodology of the subject area;

- explain the influence of design parameters of aviation elements and rocket-space technology on its flight characteristics;

- have ideas about methods of ensuring the stability and controllability of aviation and rocket-space technologies;

- have the skills to determine the load on aviation structural elements stages of its life cycles. Understand the principles of fluid and gas mechanics, in particular hydraulics, aerodynamics (gas dynamics);

- describe the structure of metals and nonmetals and know the methods of modification their properties.

In addition to strict requirements for future specialists, the state also makes certain requirements for higher education institutions that train future aircraft designers, among them are:

1) identifying the particular principles and procedures for assurance the quality in higher education;

2) monitoring and periodic review of educational programs;

3) annual assessment of applicants for higher education, scientific and pedagogical and staff of higher education institutions and regular assessments results publication on the official WEB-site of the institution of higher education, on information stands and in any other way;

4) providing professional development of pedagogical, scientific and pedagogical workers;

5) ensuring the availability of the necessary resources for the educational process organization, including independent work of students, for each educational program;

6) ensuring the availability of information systems for effective management of the educational process;

7) ensuring publicity of information about educational programs, degrees higher education and qualification;

We can say for sure that the Kyiv Polytechnic Institute successfully continues all historic and actual aviation traditions. Thus, Ukraine is one of the few countries that has a full plane development cycle. Today the National Technical University of Ukraine «KPI» is rightly proud of the fact that its faculty and students laid the foundation for aviation power of our state. As a result, our country has a strong scientific and industrial potential. 


\section{References:}

1. Tobin, James (2004), To Conquer The Air: The Wright Brothers and the Great Race for Flight, New York: Simon \& Schuster.

2. Aviatsionnyiy spravochnik Rossii $i$ stran blizhnego zarubezhya, vklyuchayuschiy rukovodstvo dlya pokupatelya, (1996) [Aviation directory of Russia and neighboring countries, including a buyer's guide] / pod red. I. Shustova (gl. red.), I. Afanaseva, Germaniya, 896 p.

3. Aviatsiya: Entsiklopediya, (1994) [Aviation Encyclopedia] / Gl. red. G. P. Svischev, M.: Nauch. izd-vo «Bolshaya ros. entsik1.»: Tsentr. Aerogidrodinam, institut im. N. E. Zhukovskogo, 736 p.

4. Goncharenko, V. V. (1986), Kak lyudi nauchilis letat [How people learn to fly], K: Veselka, 176 p.

5. Goryashko, A. M. (1982), Grazhdanskaya aviatsiya Ukrainy [Civil Aviation of Ukraine], K.: Tehnika, $143 \mathrm{p}$.

6. Zenkevich, M. A. (1933), Bratya Rayt (Seriya: Zhizn zamechatelnyih lyudey) [The Wright Brothers], M.: Zhurnalno-gazetnoe ob'edinenie, $200 \mathrm{p}$.

7. Kudashev, O. S. (2004), Konstruktori i piloty-viprobuvachi [Constructors and test pilots], Istoriya tsivilnoi aviatsii Ukrainy, K., Rozd. I. P. 32-33.

8. Pershe stolittya. Ist. Oglyad, (2007) [First Sentury. Historic review] / Avt. uporyad.: V. I. Lihovodov ta In., K.: Taki spravi, $384 \mathrm{p}$.

9. Maslov, M. A. (2009), Uteryannyie pobedy sovetskoy aviatsii [Lost victories of soviet aviation], M.: Eksmo, 416 p.

10. Sobolev, D. A. (1995), Istoriya samoletov. Nachalnyi period [History of planes. Beginning], M.: «Rossiyskaya politicheskaya entsiklopediya», $343 \mathrm{p}$.

11. Haiets, I. O. (2013), Otsinka konkurentospromozhnosti ukrainskoho rynku aviabuduvannia ta yoho eksportnoho potentsialu na svitovomu rynku [Assessment of the competitiveness of the Ukrainian aircraft market and its export potential on the world market], Ekonomika ta pravo, № 1. 